\title{
Differences in the Receptor Binding Profile of Lofexidine Compared to Clonidine
}

\author{
Robert B. Raffa ${ }^{1,2,3}$, Joseph V. Pergolizzi Jr. ${ }^{1,4}$, Robert Taylor Jr.4 ${ }^{4}$, Robert P. James ${ }^{5}$, Mark Pirner ${ }^{5}$ \\ ${ }^{1}$ Neumentum, Inc., Palo Alto, CA, USA \\ ${ }^{2}$ University of Arizona College of Pharmacy, Tucson, AZ, USA \\ ${ }^{3}$ Temple University School of Pharmacy, Philadelphia, PA, USA \\ ${ }^{4}$ NEMA Research, Inc., Naples, FL, USA \\ ${ }^{5}$ US WorldMeds, LLC, Louisville, KY, USAs \\ Email: robert.raffa@temple.edu
}

How to cite this paper: Raffa, R.B., Pergolizzi Jr., J.V., Taylor Jr., R., James, R.P. and Pirner, M. (2019) Differences in the Receptor Binding Profile of Lofexidine Compared to Clonidine. Pharmacology \& Pharmacy, 10, 1-10.

https://doi.org/10.4236/pp.2019.101001

Received: October 10, 2018

Accepted: December 31, 2018

Published: January 3, 2019

Copyright $\odot 2019$ by author(s) and Scientific Research Publishing Inc. This work is licensed under the Creative Commons Attribution International License (CC BY 4.0).

http://creativecommons.org/licenses/by/4.0/

\begin{abstract}
Lucemyra $^{\bowtie}$ (lofexidine hydrochloride) has recently been approved by the US FDA for the mitigation of withdrawal symptoms to facilitate abrupt discontinuation of opioids in adults. Lofexidine is an alpha-2 adrenoceptor agonist. However, the clinical attributes of lofexidine differ in advantageous ways from the classical alpha-2 adrenoceptor agonist clonidine. In the present study, we measured the receptor binding profile of lofexidine and clonidine in an effort to gain an insight into the clinical difference(s).
\end{abstract}

\section{Keywords}

Lofexidine, Clonidine, Opioid Withdrawal, Receptor Affinity, Alpha-2 Agonist

\section{Introduction}

The current "opioid crisis" has generated a renewed interest in evaluating the benefit-risk balance in patients' administered opioids appropriately, or persons' taking opioids as part of an opioid abuse disorder (OUD) [1]. This type of evaluation has increasingly resulted in the recommendation that the patients reduce their opioid regimen, or even eliminate it. In some cases, a patient may choose to voluntarily taper their opioid medication [2]. In other cases, a person who has an OUD might have to face the reality of an abstinence imposed upon them by the legal system [3]. In both cases, despite agreement about reducing opioid intake, fear of the unpleasant and distressing physiological sequelae that occur during withdrawal inhibits compliance [4]. Fear of the stigma, even of good-intentioned efforts, is also a barrier [5]. Thus, fear of withdrawal is a strong motivating factor 


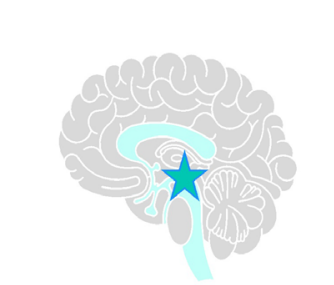

The locus coeruleus region of the brain produces norepinephrine, which mediates important bodily functions for resisting, or even avoiding, opioid taper and/or discontinuation [6] [7].

For this reason, pharmacotherapy that might help ameliorate withdrawal symptoms during either voluntary or an imposed withdrawal can serve not only a beneficial physiological function, but might also be helpful in a psychological sense, offering the individual a more optimistic view of the decision to taper their legitimate or illegitimate opioid use. In the former case, this could assist in transition to non-opioid analgesics or non-pharmacologic treatment, and in the latter case could make the decision to seek treatment a little easier.

Traditional non-opioid pharmacologic treatment to ameliorate symptoms of opioid withdrawal has mainly involved the off-label use of clonidine. This is because there is a large release of norepinephrine during withdrawal from opioids (Figure 1) [8] [9] [10]. Alpha-2 adrenoceptor agonists bind to presynaptic alpha-2 adrenoceptors and inhibit the release of norepinephrine. Clonidine is an alpha-2 adrenoceptor agonist [11]. Lofexidine is also an alpha-2 adrenoceptor agonist, but lofexidine's clinical attributes differ in several advantageous ways from clonidine [12]. The reason might be explained by differences in receptor binding.

In the present study, we report the binding affinity of lofexidine and clonidine in a variety of in vitro assays. In the assays in which the drugs were active, they displayed agonist activity (as determined by in vitro functional assays).

\section{Methods}

Lofexidine hydrochloride and clonidine hydrochloride were studied in a broad screen of receptor binding, uptake, and functional assays by Eurofins Scientific. Vectors containing the receptors were transfected into HEK293 (human embryonic kidney 293) cells, and the assays were conducted according to methods previously published [13]-[19].

The receptor binding affinity of compounds was calculated as the percent
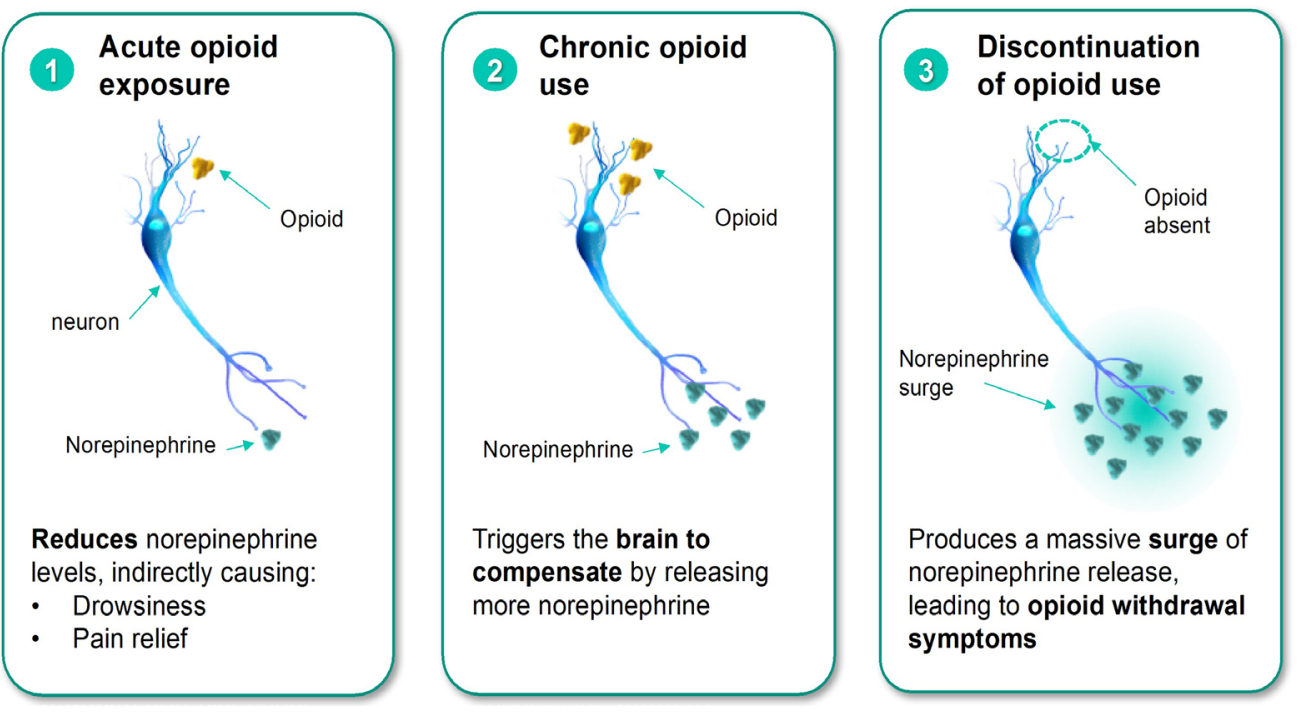

Figure 1. Pictorial representation of the effect of acute and prolonged opioid exposure on norepinephrine in the locus cœruleus. 
inhibition of the binding of a radioactively labeled ligand specific for each of the targets. Functional cellular agonist effect (efficacy) was calculated as percent of control response to a known reference agonist. A difference greater than $50 \%$ is considered significant in these assays.

EC50 values (the concentrations of test compounds estimated to produce a half-maximal response in an assay) were determined by non-linear regression analysis of the concentration-response curves that were generated, with mean replicate values, using Hill equation curve fitting [20].

\section{Results}

Clonidine and lofexidine were inactive in kappa opioid receptor assay (rat recombinant $\mathrm{CHO}$ cells, $0.3 \mu \mathrm{M} \mathrm{U}-50488,10 \mathrm{~min}, 37^{\circ} \mathrm{C}$ ), $5-\mathrm{HT}_{2 \mathrm{~A}}$ (human recombinant HEK-293 cells, $10 \mu \mathrm{M}$ serotonin, $30 \mathrm{~min}, 37^{\circ} \mathrm{C}$ ), $5-\mathrm{HT}_{2 \mathrm{~B}}$ (human recombinant $\mathrm{CHO}$ cells, $1 \mu \mathrm{M}$ serotonin, $30 \mathrm{~min}, 37^{\circ} \mathrm{C}$ ), 5-HT transporter (human recombinant $\mathrm{CHO}$ cells, $2 \mathrm{nM}$ imipramine, $60 \mathrm{~min}$, room temperature), and MAO-A (rat cerebral cortex, $10 \mathrm{nM}$ Ro-41-1049, $60 \mathrm{~min}, 37^{\circ} \mathrm{C}$ ). Clonidine displayed significant binding affinity and agonist functional activity (pEC50 $\geq 5 \mathrm{M}$ ) at the following receptors: alpha-adrenoceptor sites: alpha-1A, alpha-2A, and alpha-2C (Figure 2). It was devoid of significant activity (agonist or antagonist) at the other sites examined.

Lofexidine displayed significant binding affinity and agonist functional activity (viz., pEC50 $\geq 5 \mathrm{M}$ ) at alpha-adrenoceptor receptors alpha-1A, alpha-2A, alpha-2B, and alpha-2C. In addition to the activity at alpha-adrenoceptors, lofexidine also displayed significant agonist activity at dopamine $\mathrm{D}_{25}$, serotonin $5-\mathrm{HT}_{1 \mathrm{~A}}$, and $5-\mathrm{HT}_{1 \mathrm{~B}}$ (Figure 3 ).

The receptor binding affinity of lofexidine at these sites is shown in Figure 4. Similar to the profile of clonidine, lofexidine has affinity for several alpha-adrenoceptor subtypes. But unlike clonidine, lofexidine has affinity for other receptors, including $5-\mathrm{HT}_{1 \mathrm{~A}}, 5-\mathrm{HT}_{1 \mathrm{~B}}$, and dopamine $\mathrm{D}_{2 \mathrm{~S}}$.

The chemical structures of lofexidine (2-[1-(2,6-Dichlorophenoxy)ethyl]-4,5dihydro- $1 H$-imidazole) and of clonidine ( $N$-(2,6-Dichlorophenyl)-4,5-dihydro$1 H$-imidazol-2-amine) are shown in Figure 5.

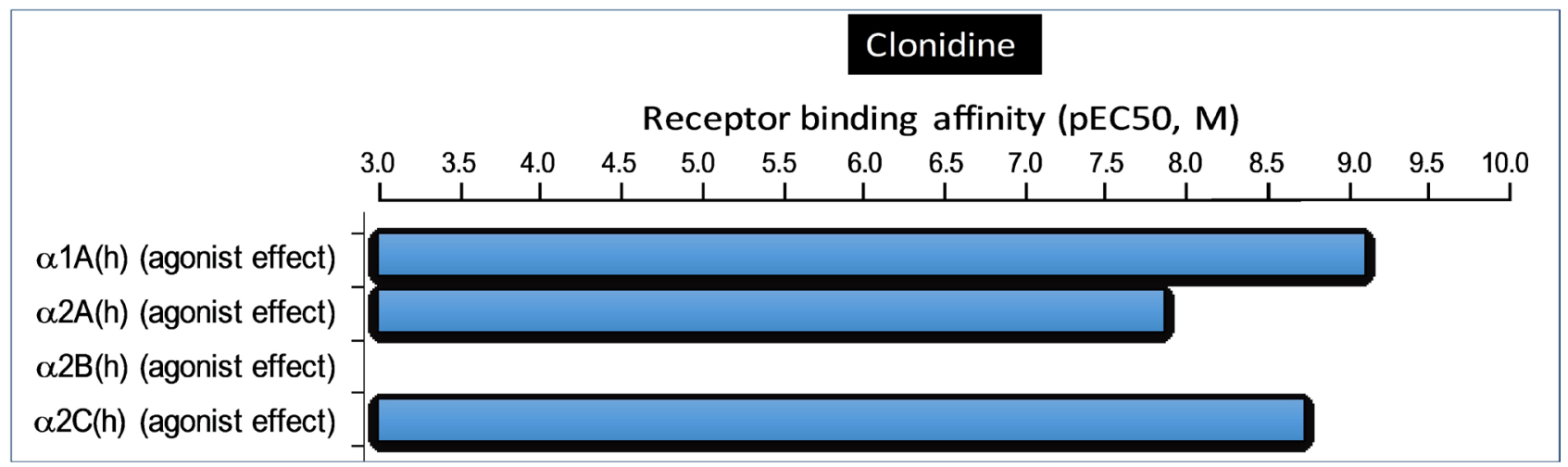

Figure 2. Summary of receptor binding profile of clonidine. 

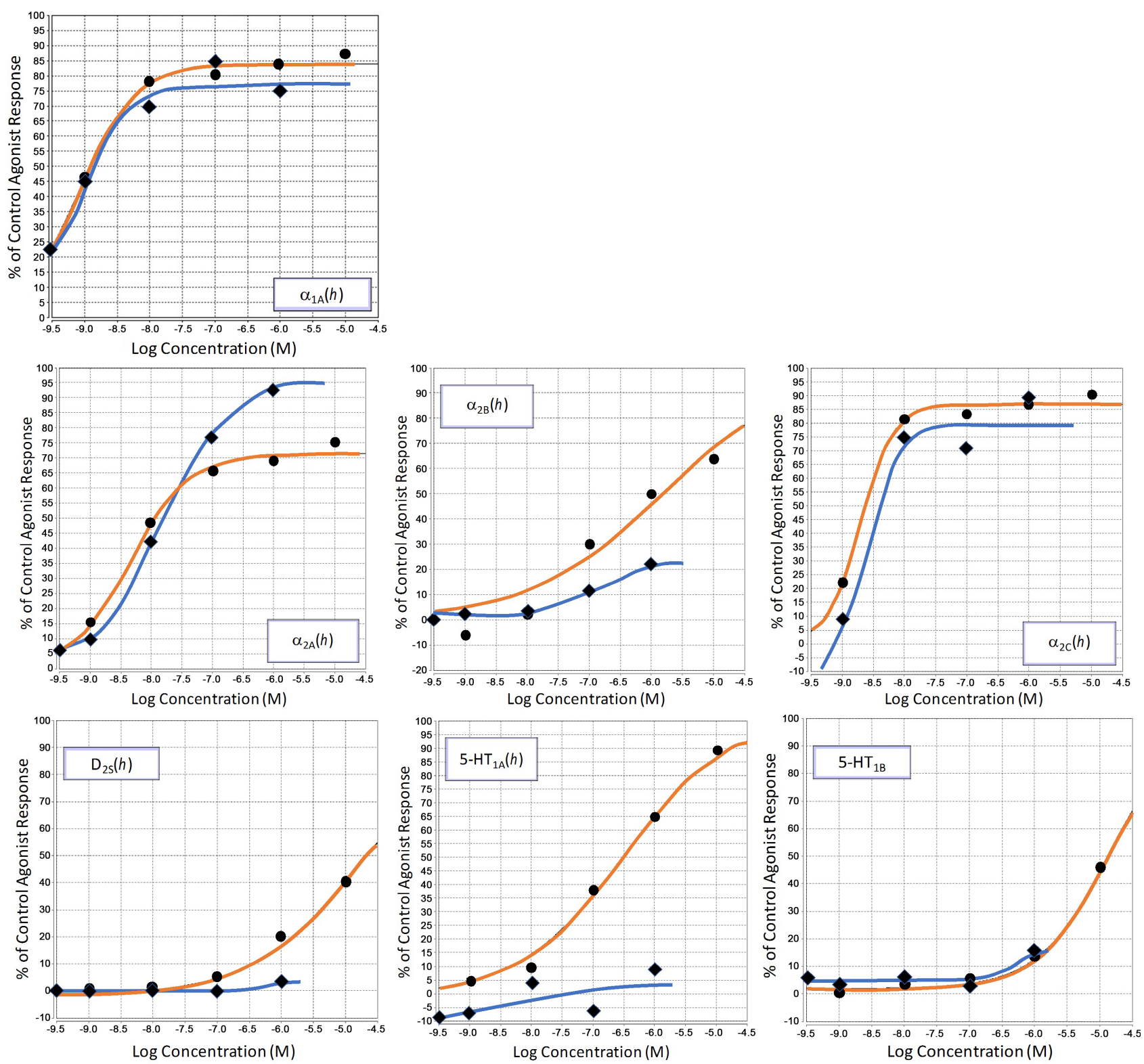

Figure 3. Dose-response curves of lofexidine (dots) and clonidine (triangles) in in vitro assays.

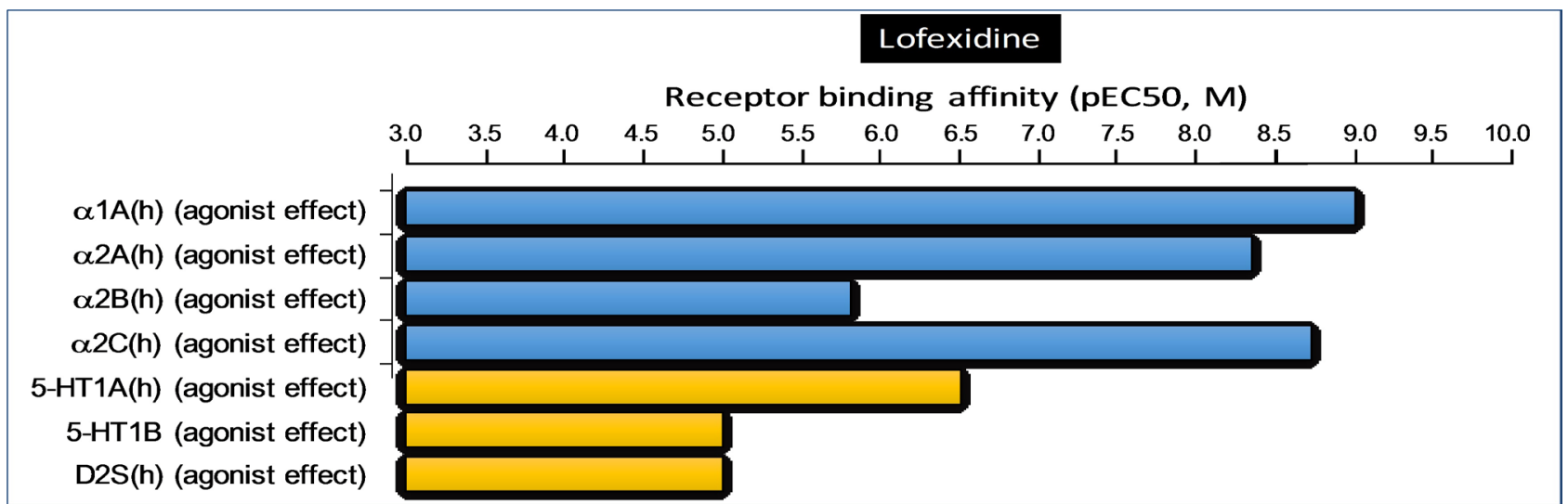

Figure 4. Summary of receptor binding profile of lofexidine. 
<smiles>Clc1cccc(Cl)c1NC1=NCCN1</smiles><smiles>CC(Oc1c(Cl)cccc1Cl)C1=NCCN1</smiles>

Figure 5. Chemical structure comparison of lofexidine and clonidine.

\section{Discussion}

For a significant number of people the fear of experiencing negative symptoms during voluntary or forced withdrawal from opioid therapy or abuse is a strong deterrent to seeking help or to compliance to effective tapering regimens, and the combination of uncomfortable symptoms and craving makes completion of withdrawal difficult [21] [22] [23]. Thus, a treatment that can lessen opioid withdrawal symptoms used in conjunction with other treatment modalities results in better outcomes [24].

Based on several studies in rodents and monkeys suggesting that norepinephrine is involved in opioid withdrawal [25] [26] [27] [28] [29], Gold et al. (1978) [30] reported early successful experience with the use of the alpha-2 adrenoceptor agonist clonidine to treat symptoms of opioid withdrawal in five patients, followed by a double-blind, placebo-controlled, cross-over trial involving 11 participants [31]. Washton et al. (1980) [32] [33] also reported positive results with clonidine. Other treatments that also decrease noradrenergic tone, such as beta-adrenoceptor antagonism [34] [35] and inhibition of norepinephrine synthesis [36] [37] have been reported to have positive effects on opioid withdrawal symptoms, but they are not as potent on locus cœruleus inhibitory effects or in blocking the physiological effects of heightened noradrenergic activity in clinical doses. Hence, the special value of an alpha-2 adrenoceptor agonist action stands out. However, although clonidine has been effective, it has consistently been reported to be associated with adverse events, in particular, significant changes (drops) in blood pressure [38] [39] [40].

Lofexidine (racemate of $R$-(+)- and $S$-(-) enantiomers, dexlofexidine and levlofexidine, respectively) is a full agonist at alpha-2 adrenoceptors [41] [42] [43] [44] [45]. It was originally reported to be effective in easing the symptoms in opioid-dependent patients by Washton et al. in 1981 [46]. It was approved for use in opioid detoxification in the United Kingdom, most of the European Union, and other countries in the 1980s and 1990s. Its efficacy in amelioration of opioid withdrawal symptoms has subsequently been demonstrated in several studies, and according to a recent Cochrane review [24], with fewer adverse effects and better safety profile than clonidine. The same conclusion was reached in an earlier review by Gowing et al. (2002) [47]. Notably, the lower incidence of hypotension has been highlighted as the basis for distinguishing lofexidine from clonidine for use in treating the symptoms of opioid withdrawal, and for making it more suitable for this use in outpatient settings [47]. 
The present study reveals another interesting difference, at the receptor level, between lofexidine and clonidine. Whereas both of the drugs bind to alpha-adrenoceptors, lofexidine displays additional binding that clonidine does not: most notably to $5-\mathrm{HT}_{1 \mathrm{~A}}$ receptors. $5-\mathrm{HT}_{1 \mathrm{~A}}$ receptors have independently been linked to opioid withdrawal. 5-HT levels decrease during withdrawal from opioids [48]. And both opioid withdrawal and post-withdrawal stress induce differential alterations in mRNA expression for genes that regulate 5-HT located in DRN (serotonergic dorsal raphe nucleus) of rats [49]. $5-\mathrm{HT}_{1 \mathrm{~A}}$ receptors are located on cell bodies and dendrites of DRN neurons and they function to maintain 5-HT homeostasis by regulating 5-HT synthesis and release [50] [51]. A compound with 5- $\mathrm{HT}_{1 \mathrm{~A}}$ agonist properties has been recently reported to decrease the expression of morphine withdrawal symptoms in opioid-dependent mice [52] [53].

\section{Perspective and Conclusions}

For a significant number of people, the fear of experiencing negative symptoms during withdrawal from opioids deters compliance with taper regimens and seeking treatment opportunities. Amelioration of withdrawal symptoms results in improved outcomes. The alpha-2 agonist lofexidine has been used for this purpose in several countries for many years, and has recently been approved in the US It is as effective as the standard alpha- 2 agonist clonidine, but has a better safety profile. The present study potentially opens a window into a mechanistic understanding of the differentiating attributes of lofexidine and clonidine. Interestingly, the results of this study reveal that lofexidine, but not clonidine, has affinity for $5-\mathrm{HT}_{1 \mathrm{~A}}$ receptors. This is particularly interesting in light of studies demonstrating: 1) changes in 5- $\mathrm{HT}_{1 \mathrm{~A}}$ mRNA during withdrawal, and 2) the decreased expression of morphine withdrawal symptoms in mice administered a compound having $5-\mathrm{HT}_{1 \mathrm{~A}}$ agonist activity.

Based on the above, it is intriguing to speculate that a drug that has dual agonist action at alpha- 2 adrenoceptors and anxiolytic $5-\mathrm{HT}_{1 \mathrm{~A}}$ receptors will be more effective in treating opioid withdrawal symptoms at doses that produce less adverse effects than single-mechanism alpha-2 agonists.

\section{Conflicts of Interest}

The authors declare no conflicts of interest regarding the publication of this paper.

\section{References}

[1] Dasgupta, N., Beletsky, L. and Ciccarone, D. (2018) Opioid Crisis: No Easy Fix to Its Social and Economic Determinants. American Public Health Association, 108, 182-186. https://doi.org/10.2105/AJPH.2017.304187

[2] Zhou, K., Jia, P., Bhargava, S., et al. (2017) Opioid Tapering in Patients with Prescription Opioid Use Disorder: A Retrospective Study. Scandinavian Journal of Pain, 17, 167-173. https://doi.org/10.1016/j.sjpain.2017.09.005 
[3] Reichel, C.M. and Bevins, R.A. (2009) Forced Abstinence Model of Relapse to Study Pharmacological Treatments of Substance Use Disorder. Current Drug Abuse Reviews, 2, 184-194. https://doi.org/10.2174/1874473710902020184

[4] Peterson, J.A., Schwartz, R.P., Mitchell, S.G., Agar, M.H., et al. (2010) Why Don't Out-of-Treatment Individuals Enter Methadone Treatment Programmes? International Journal of Drug Policy, 21, 36-42.

https://doi.org/10.1016/j.drugpo.2008.07.004

[5] Olsen, Y. and Sharfstein, J.M. (2014) Confronting the Stigma of Opioid Use Disorder-And Its Treatment. JAMA, 311, 1393-1394.

https://doi.org/10.1001/jama.2014.2147

[6] Bechara, A., Nader, K. and van der Kooy, D. (1998) A Two-Separate-MotivationalSystems Hypothesis of Opioid Addiction. Pharmacology Biochemistry and Behavior, 59, 1-17. https://doi.org/10.1016/S0091-3057(97)00047-6

[7] O’Brien, C.P., Childress, A.R., McLellan, A.T., Ehrman, R. and Ternes, J.W. (1988) Types of Conditioning Found in Drug-Dependent Humans. NIDA Research Monograph, 84, 44-61.

[8] Maldonado, R. (1997) Participation of Noradrenergic Pathways in the Expression of Opiate Withdrawal: Biochemical and Pharmacological Evidence. Neuroscience \& Biobehavioral Reviews, 21, 91-104. https://doi.org/10.1016/0149-7634(95)00061-5

[9] Van Bockstaele, E.J., Reyes, B.A., Valentino, R.J. (2010) The Locus Coeruleus: A Key Nucleus Where Stress and Opioids Intersect to Mediate Vulnerability to Opiate Abuse. Brain Research, 1314, 162-174. https://doi.org/10.1016/j.brainres.2009.09.036

[10] Kosten, T.R. and George, T.P. (2002) The Neurobiology of Opioid Dependence: Implications for Treatment. Science and Practice Perspectives, 1, 13-20. https://doi.org/10.1151/spp021113

[11] Giovannitti Jr., J.A., Thoms, S.M. and Crawford, J.J. (2015) Alpha-2 Adrenergic Receptor Agonists: A Review of Current Clinical Applications. Anesthesia Progress, 62, 31-39. https://doi.org/10.2344/0003-3006-62.1.31

[12] Vartak, A.P. (2014) The Preclinical Discovery of Lofexidine for the Treatment of Opiate Addiction. Expert Opinion on Drug Discovery, 9, 1371-1377. https://doi.org/10.1517/17460441.2014.962995

[13] Regan, J.W., Kobilka, T.S., Yang-Feng, T.L., et al. (1988) Cloning and Expression of a Human Kidney cDNA for an Alpha 2-Adrenergic Receptor Subtype. Proceedings of the National Academy of Sciences of the United States of America, 85, 6301-6305. https://doi.org/10.1073/pnas.85.17.6301

[14] Giles, H., Lansdell, S.J., Bolofo, M.-L., Wilson, H.L. and Martin, G.R. (1996) Characterization of a 5-HT1B Receptor on CHO Cells: Functional Responses in the Absence of Radioligand Binding. British Journal of Pharmacology, 117, 1119-1126. https://doi.org/10.1111/j.1476-5381.1996.tb16705.x

[15] Vicentic, A., Robeva, A., Rogge, G., Uberti, M. and Minneman, K.P. (2002) Biochemistry and Pharmacology of Epitope-Tagged $\alpha_{1}$-Adrenergic Receptor Subtypes. Journal of Pharmacology and Experimental Therapeutics, 302, 58-65. https://doi.org/10.1124/jpet.302.1.58

[16] Eason, M.G., Kurose, H., Holt, B.D., Raymond, J.R. and Liggett, S.B. (1992) Simultaneous Coupling of Alpha 2-Adrenergic Receptors to two G-Proteins with Opposing Effects. Subtype-Selective Coupling of Alpha 2C10, Alpha 2C4, and Alpha 2C2 Adrenergic Receptors to Gi and Gs. Journal of Biological Chemistry, 267, 15795-15801. 
[17] Bavadekar, S.A., Ma, G., Mustafa, S.M., et al. (2006) Tethered Yohimbine Analogs as Selective Human Alpha $_{2 \mathrm{C}}$-Adrenergic Receptor Ligands. Journal of Pharmacology and Experimental Therapeutics, 319, 739-748. https://doi.org/10.1124/jpet.106.105981

[18] Payne, S.L., Johansson, A.M. and Strange, P.G. (2002) Mechanisms of Ligand Binding and Efficacy at the Human $\mathrm{D}_{2 \text { (Short) }}$ Dopamine Receptor. Journal of Neurochemistry, 82, 1106-1117. https://doi.org/10.1046/j.1471-4159.2002.01046.x

[19] Martel, J.C., Assie, M.-B., Bardin, L., et al. (2009) 5-HT1A Receptors Are Involved in the Effects of Xaliproden on G-Protein Activation, Neurotransmitter Release and Nociception. British Journal of Pharmacology, 158, 232-242. https://doi.org/10.1111/j.1476-5381.2009.00249.x

[20] Barlow, R. and Blake, J.F. (1989) Hill Coefficients and the Logistic Equation. Trends in Pharmacological Sciences, 10, 440-441. https://doi.org/10.1016/S0165-6147(89)80006-9

[21] Mattick, R.P. and Hall, W. (1996) Are Detoxification Programmes Effective? The Lancet, 347, 97-100. https://doi.org/10.1016/S0140-6736(96)90215-9

[22] Tetrault, J.M. and O'Connor, P.G. (2009) Management of Opioid Intoxication and Withdrawal. In: Ries, R.K., Fiellin, D.A., Miller, S.C. and Siatz, R., Eds., Principles of Addiction Medicine, 4th Edtion, Wolters Kluwer/Lippincott Williams \& Wilkins, Philadelphia, 589-606.

[23] Farrell, M. (1994) Opiate Withdrawal. Addiction, 89, 1471-1475. https://doi.org/10.1111/j.1360-0443.1994.tb03745.x

[24] Gowing, L., Farrell, M., Ali, R. and White, J.M. (2016) Alpha ${ }_{2}$-Adrenergic Agonists for the Management of Opioid Withdrawal. Cochrane Database of Systematic Reviews. https://www.cochranelibrary.com/cdsr/doi/10.1002/14651858.CD002024.pub3/full

[25] Cedarbaum, J.M. and Aghajanian, G.K. (1977) Catecholamine Receptors on Locus Coeruleus Neurons: Pharmacological Characterization. European Journal of Pharmacology, 44, 375-385. https://doi.org/10.1016/0014-2999(77)90312-0

[26] Svensson, T.H., Bunney, B.S. and Aghajanian, G.K. (1975) Inhibition of Both Noradrenergic and Serotonergic Neurons in Brain by the Alpha-Adrenergic Agonist Clonidine. Brain Research, 92, 291-306. https://doi.org/10.1016/0006-8993(75)90276-0

[27] Gomes, C., Svensson, T.H. and Trolin, G. (1976) Effects of Morphine on Central Catecholamine Turnover, Blood Pressure and Heart Rate in the Rat. NaunynSchmiedeberg's Archives of Pharmacology, 294, 141-147. https://doi.org/10.1007/BF00507846

[28] Tseng, L.F., Loh, H.H. and Wei, E.T. (1975) Effects of Clonidine on Morphine Withdrawal Signs in the Rat. European Journal of Pharmacology, 30, 93-99. https://doi.org/10.1016/0014-2999(75)90208-3

[29] Lewis, M.J., Costa, J.L., Jacobowitz, D.M. and Margules, D.L. (1976) Tolerance, Physical Dependence and Opiod-Seeking Behavior: Dependence of Diencephalic Norepinephrine. Brain Research, 107, 156-165. https://doi.org/10.1016/0006-8993(76)90105-0

[30] Gold, M.S., Redmond Jr., D.E. and Kleber, H.D. (1978) Clonidine in Opiate Withdrawal. The Lancet, 1, 929-930. https://doi.org/10.1016/S0140-6736(78)90699-2

[31] Gold, M.S., Redmond Jr., D.E. and Kleber, H.D. (1978) Clonidine Blocks Acute Opiate-Withdrawal Symptoms. The Lancet, 2, 599-602. 
https://doi.org/10.1016/S0140-6736(78)92823-4

[32] Washton, A.M. and Resnick, R.B. (1980) Clonidine for Opiate Detoxification: Outpatient Clinical Trials. American Journal of Psychiatry, 137, 1121-1122. https://doi.org/10.1176/ajp.137.9.1121

[33] Washton, A.M., Resnick, R.B. and Rawson, R.A. (1980) Clonidine for Outpatient Opiate Detoxification. The Lancet, 1, 1078-1079. https://doi.org/10.1016/S0140-6736(80)91515-9

[34] Grosz, H.J. (1972) Narcotic Withdrawal Symptoms in Heroin Users Treated with Propranolol. The Lancet, 2, 564-566. https://doi.org/10.1016/S0140-6736(72)91959-9

[35] Resnick, R.B., Kestenbaum, R.S., Schwartz, L.K. and Smith, A. (1976) Evaluation of Propranolol in Opiate Dependence. Archives of General Psychiatry, 33, 993-997. https://doi.org/10.1001/archpsyc.1976.01770080111011

[36] Davis, W.M. and Smith, S.G. (1973) Blocking of Morphine Based Reinforcement by Alpha-Methyltyrosine. Life Sciences, 12, 185-191. https://doi.org/10.1016/0024-3205(73)90132-X

[37] Pozuelo, J. and Kerr, F.W. (1972) Suppression of Craving and Other Signs of Dependence in Morphine-Addicted Monkeys by Administration of Alpha-MethylPara-Tyrosine. Mayo Clinic Proceedings, 47, 621-628.

[38] Cami, J., de Torres, S., San, L., et al. (1985) Efficacy of Clonidine and of Methadone in the Rapid Detoxification of Patients Dependent on Heroin. Clinical Pharmacology \& Therapeutics, 38, 336-341. https://doi.org/10.1038/clpt.1985.182

[39] Kleber, H.D., Riordan, C.E., Rounsaville, B., et al. (1985) Clonidine in Outpatient Detoxification from Methadone Maintenance. Archives of General Psychiatry, 42, 391-394. https://doi.org/10.1001/archpsyc.1985.01790270081009

[40] San, L., Cami, J., Peri, J.M., Mata, R., Porta, M. and CamÍ, J. (1990) Efficacy of Clonidine, Guanfacine and Methadone in the Rapid Detoxification of Heroin Addicts: A Controlled Clinical Trial. British Journal of Addiction, 85, 141-147. https://doi.org/10.1111/j.1360-0443.1990.tb00634.x

[41] Biedermann, J., Leon-Lomeli, A., Borbe, H.O. and Prop, G. (1986) Two Stereoisomeric Imidazoline Derivatives: Synthesis and Optical and Alpha 2-Adrenoceptor Activities. Journal of Medicinal Chemistry, 29, 1183-1188. https://doi.org/10.1021/jm00157a011

[42] Jarrott, B., Louis, W.J. and Summers, R.J. (1983) Characterization of Central Alpha-Adrenoceptors Using 3H-Clonidine and Its Derivatives. Chest, 83, 339-340. https://doi.org/10.1378/chest.83.2_Supplement.339

[43] Summers, R.J., Jarrott, B. and Louis, W.J. (1980) Displacement of [3H]Clonidine Binding by Clonidine Analogues in Membranes from Rat Cerebral Cortex. European Journal of Pharmacology, 66, 233-241.

https://doi.org/10.1016/0014-2999(80)90147-8

[44] Wilffert, B., Mathy, M.J., Batink, H.D., et al. (1985) Interference of Enantiomers of Lofexidine with Alpha-Adrenoceptors. Archives Internationales de Pharmacodynamie et de Therapie, 273, 18-32.

[45] Timmermans, P.B., van Kemenade, J.E., Harms, Y.M., Prop, G., Graf, E. and van Zwieten, P.A. (1983) Binding of (+/-)-3H-Lofexidine to Alpha-Adrenoceptors in Membranes from Rat Brain. Archives Internationales de Pharmacodynamie et de Therapie, 261, 23-35.

[46] Washton, A.M., Resnick, R.B. and Rawson RA. (1981) Lofexidine, a Clonidine 
Analogue Effective in Opiate Withdrawal. The Lancet, 317, 991-993. https://doi.org/10.1016/S0140-6736(81)91747-5

[47] Gowing, L.R., Farrell, M., Ali, R.L. and White, J.M. (2002) $\alpha_{2}$-Adrenergic Agonists in Opioid Withdrawal. Addiction, 97, 49-58. https://doi.org/10.1046/j.1360-0443.2002.00037.x

[48] Tao, R., Ma, Z. and Auerbach, S.B. (1998) Alteration in Regulation of Serotonin Release in Rat Dorsal Raphe Nucleus after Prolonged Exposure to Morphine. Journal of Pharmacology and Experimental Therapeutics, 286, 481-488.

[49] Lunden, J.W. and Kirby, L.G. (2013) Opiate Exposure and Withdrawal Dynamically Regulate mRNA Expression in the Serotonergic Dorsal Raphe Nucleus. Neuroscience, 254, 160-172. https://doi.org/10.1016/j.neuroscience.2013.08.071

[50] Hamon, M., Fattaccini, C.M., Adrien, J., Gallissot, M.C., Martin, P. and Gozlan, H. (1988) Alterations of Central Serotonin and Dopamine Turnover in Rats Treated with Ipsapirone and Other 5-Hydroxytryptaminela Agonists with Potential Anxiolytic Properties. Journal of Pharmacology and Experimental Therapeutics, 246, 745-752.

[51] Sharp, T., Bramwell, S.R. and Grahame-Smith, D.G. (1989) 5-HT1 Agonists Reduce 5-Hydroxytryptamine Release in Rat Hippocampus in Vivo as Determined by Brain Microdialysis. British Journal of Pharmacology, 96, 283-290. https://doi.org/10.1111/j.1476-5381.1989.tb11815.x

[52] Del Bello, F., Diamanti, E., Giannella, M., et al. (2012) Low Doses of Allyphenyline and Cyclomethyline, Effective against Morphine Dependence, Elicit an Antidepressant-like Effect. ACS Medicinal Chemistry Letters, 3, 535-539. https://doi.org/10.1021/ml300064v

[53] Del Bello, F., Mattioli, L., Ghelfi, F., Giannella, M., et al. (2010) Fruitful Adrenergic Alpha(2C)-Agonism/Alpha(2A)-Antagonism Combination to Prevent and Contrast Morphine Tolerance and Dependence. Journal of Medicinal Chemistry, 53, 7825-7835. https://doi.org/10.1021/jm100977d 